\title{
EDUKACYJNE I SOCJALIZACYJNE ASPEKTY KULTURY POPULARNEJ. FASCYNACJE LITERACKIE MŁODEGO POKOLENIA
}

\author{
Wiktoria Kiwior, wiktoria.kiwior1@gmail.com \\ Uniwersytet Wrocławski \\ Pl. Uniwersytecki 1, 50-137 Wrocław
}

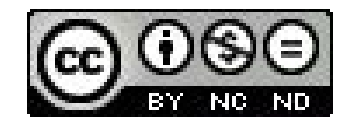

\begin{abstract}
Abstrakt
Artykuł dotyczy edukacyjnego oraz socjalizacyjnego potencjału kultury popularnej, która ma niebagatelny wpływ na funkcjonowanie młodego pokolenia. Dzisiejsza rzeczywistość młodego człowieka przesycona jest przekazami medialny$\mathrm{mi}$, a jej odbiór zapośredniczony przez środki masowego przekazu. Literatura popularna stanowi ważny obszar kultury popularnej, a dzieła zaliczane w jej poczet to bestsellery rynków księgarskich. Celem badań, przeprowadzonych za pomocą wywiadów swobodnych było określenie miejsca, roli oraz funkcji literatury w życiu adolescentów, określenie fascynacji literackich oraz dotarcie do edukacyjnych i socjalizacyjnych wymiarów literatury popularnej.

Słowa kluczowe: kultura popularna, literatura popularna, czytelnictwo, młodzież
\end{abstract}

Educational and socialization aspects of popular culture. Literary fascination of the young generation

\section{Abstract}

The aim of the article is to show a socialization and education potential of popular culture, which has a substantial influence on the today's young generation. Nowadays young people live in the reality, which is dominated by different types of media. Popular culture is a very important agenda of socializing and area of non-formal education and popular literature is a big part of popular culture. The studies have been carried out by the free interview. Purpose of the studies was to determine the place, role and function of literature in the lives of adolescents, their literary fascination and determine the education and socialization potential of literature, especially of popular literature.

Keywords: youth, popular culture, reading, popular literature

Książki były dominującym środkiem przekazu kulturowego od czasu wynalezienia druku, a literatura stała się nieodłączną częścią procesu socjalizacji i edukacji. Słowo drukowane traci jednak na znaczeniu w skutek rozwoju nowych mediów, które są atrakcyjniejsze, łatwiejsze w odbiorze i bardziej sugestywne, ale jednocześnie bardziej schematyczne i uproszczone. Mimo tego, „"czytanie wciąż oddziałuje na zbiorową wyobraźnię ${ }^{\prime \prime}$, chociaż gwałtownie słabnie jego popularność, na co wskazują coroczne badania poziomu czytelnictwa prowadzane m. in. przez Bibliotekę Narodową. W szczególnej sytuacji znajdują się młodzi ludzie, dla których nowe media oraz przekazywana za ich pośrednictwem kultura popularna to środowisko funkcjonowania, z którym stykają się niemal od urodzenia. Refleksja nad czytelnictwem młodzieży w rzeczywistości zdominowanej kulturą popularną oraz nowymi środkami przekazu stała się podstawą przeprowadzonych badań, które zaprezentowane będą w niniejszym artykule. Zarówno przeprowadzone badania, jak $\mathrm{i}$ analiza rynków księgarskich wskazują, iż wybory czytelnicze adolescentów w dużej mierze zamykają się w obrębie wytworów literatury popularnej i bestsellerów opakowanych w szeroko zakrojoną strategię marketingową. Literatura obecnie nie jest już samoistnym, autonomicznym przedmiotem poznania, bowiem zmianie podlega jej sytuacja komunikacyjna. Dzisiejsza kultura podlega multimedializacji, której skutki najbardziej widoczne są w twórczości masowej. Młoda generacja wychowana jest na multimedialnym odbiorze. Pokoleniu temu ciężko jest powrócić do odczytania wymagającego niemałego trudu kodu literackiego². Wszelkim treściom docierającym do młodych ludzi, a szczególnie tym wywołującym szeroką społeczną dyskusję, jak wskazuje Danuta Kowalewska, należy się odpowiedni klimat przekazu oraz gotowość do otwartej dyskusji. Rzeczywistość współczesna powoduje, że dzieci muszą szybciej dorastać, nakłada obowiązek oswojenia świata, którego bardzo często nie rozumieją dorośli. W sytuacji, kiedy młodzi ludzie poszukują wzorców i drogowskazów na

1 T. Zatorska, Rozważania naukowe nad czytelnictwem, http://szkola.net/awans/art.php?id=2090, 26.05.2012.

2 P. Kowalski, Miejsce literatury w kulturze popularnej, „Kultura Popularna” 2005, nr 2, s. 123-124. 
miarę ich wieku i rzeczywistości jaka ich otacza, nie możemy bać się „ „uchów”, w które nie wierzymy, ale towarzyszyć młodemu czytelnikowi w jego poszukiwaniach ${ }^{3}$. Kultura popularna to dziś dominujący rodzaj kultury, ze wglądu na to, iż oddziałuje na nas nieustannie poprzez wszystkie dostępne media i właściwie nie jest już możliwa ucieczka od niej. Stała się istotnym elementem nabywania wiedzy o świecie, tworzenia tożsamości i porządkowania relacji społecznych, poprzez swoje nośniki kształtuje świadomość społeczną. Szczególnie znacząco wpływa na młodzież, która jest w fazie tworzenia własnej tożsamości orz spójnego systemu aksjonormatywnego, odrzucając przyjmowane dotąd wartości, normy i autorytety. Śledząc oddziaływanie kultury popularnej możemy zauważyć, iż jest ona nieprzebranym źródłem edukacji i socjalizacji, szczególnie dla młodego pokolenia ${ }^{4}$. W jej badaniu ważne jest jednak, aby nasze spojrzenie pobawione było wartościowania, aby można było przyjrzeć się kulturze, w której zanurzona jest młodzież.

„CZłowiek nie rodzi się czytelnikiem, ale staje się nim dopiero na skutek wrastania w konkretną kulturę ${ }^{\prime 5}$. Kultura jest źródłem socjalizacji i edukacji, co podkreśla między innymi definicja Antoniny Kłoskowskiej, która analizując rozwój pojęcia „kultura” stwierdza, iż jest to „względnie zintegrowana całość obejmująca zachowania ludzi przebiegające według wspólnych dla zbiorowości społecznej wzorów wykształconych i przyswajanych w toku interakcji oraz zawierająca wytwory takich zachowan'”6. Warto zacząć od zastanowienia się w jakim kontekście funkcjonuje kultura współczesna i jaki jest charakter dzisiejszej rzeczywistości, która ją kształtuje. Mamy obecnie do czynienia z niezwykle dynamicznymi zmianami i przekształceniami we wszystkich aspektach życia. Współczesna rzeczywistość nie posiada już stałego charakteru, jednolitych wartości, norm i reguł postępowania, wspótistnieje ze sobą wiele różnorodnych wzorów kulturowych, przenikają się wzajemnie różne ideologie i wzorce aksjonormatywne. Czasy współczesne charakteryzują się ciagłym pośpiechem, wszechobecną tymczasowościa, brakiem stabilnych punktów odniesienia, co wpływa na poczucie zagubienia w chaosie różnorodności współczesnej kultury. Obecna epoka przez współczesnych myślicieli nazywana jest ponowoczesnościa, w której mówimy o upadku wielkich narracji i braku poszukiwania uniwersalistycznej prawdy. Następuje dekonstrukcja tradycyjnego porządku, uważanego za jedyny i bezwzględnie obowiązujący. Rzeczywistość to efekt procesów społecznych uznawanych jako normalne tylko w określonym kontekście. Nie zakłada się, iż jednostka posiada stabilną oraz jasno określoną tożsamość 7 . Tworzy ją wykorzystując symbole kulturowe, dowolnie układając puzzle znaków kulturowych, znajdujących się w kulturze w której funkcjonuje, a która obecnie jest najczęściej kulturą popularną. Decydującą rolę w konstruowaniu tożsamości młodzieży odgrywa popkultura, brak jest w ich życiu wielkich idei i metanarracji, a dominują raczej drobne codzienne sprawy. Zanika styl życia oparty na refleksji i poszukiwaniu sensu egzystencji. Mimo funkcjonowania w świecie bez drogowskazów, zrelatywizowania wartości i norm młodzież nie boi się żyć, ma poczucie sprawstwa i kontroli nad rzeczywistością. Żyjemy w czasach kultury upozorowanej, zdominowanej przez mass media, które nie tylko reprezentują rzeczywistość, ale przede wszystkim ją kreują. Inflacji uległy dawniej ważne znaczenia w kakofonii słów, dźwięków, obrazów, symboli i kontekstów. Obowiązuje kult sukcesu - posiadania władzy i pieniędzy lub popularności i sławy, a także wszechobecny kult ciała i seksualności, silnie determinujący obraz własnej osoby jaki posiadają młodzi ludzie?. Warto również zastanowić się, czym charakteryzuje się współczesne młode pokolenie. Młodzież to dynamiczna „konstrukcja społeczna”, silnie zakorzeniona w określonych warunkach historycznych. W myśleniu i działaniu tej kategorii najszybciej ujawniają się wszelkie oznaki zmian społecznych, jest to więc kategoria silnie nacechowana emocjonalnie, stanowi miejsce gdzie najsilniej kontynuowana jest tradycja, ale też gdzie zaistnieć może z wielkim dynamizmem bunt, jak widzimy chociażby na przykładzie rewolucji lat sześćdziesiątych. Szczególnie istotny jest okres późnej adolescencji, który obejmuje w ujęciu Erika Eriksona wiek od 18 do 22 roku życia. Na tym etapie dochodzi do stabilizowania się tożsamości, rodzi się dojrzała koncepcja własnego „,Ja", młody człowiek na nowo kształtuje hierarchię wartości, uzyskuje zdolności potrzebne do pełnienia ról społecznych w dorosłym życiu oraz określenia swojego miejsca w świecie ${ }^{10}$. Jest to okres krytycznej refleksji nad własną egzystencja, spowodowany intensywnym rozwojem

3 D. Kowalewska, Harry i czary-mary, czyli o wartościach edukacyjnych w cyklu powieści „Harry Potter” J. K. Rowling, Kraków 2005, s. 8-12.

4 M. Gałuszka, Między przyjemnościa, a rytuałem. Serial telewizyjny w kulturze popularnej, Lódź 1996, s. 20.

5 J. Papuzińska, Inicjacje literackie: problemy pierwszych kontaktów dziecka z ksiazka, Warszawa 1988, s.10.

6 A. Kłoskowska, Kultura masowa. Krytyka i obrona, Warszawa 2005, s. 40. 456.

Melosik, Pedagogika postmodernizmu, [w:] Z. Kwieciński, B. Śliwerski (red.), Pedagogika. Podręcznik akademicki, T. I, Warszawa 2003, s. 452-

8 W. Jakubowski, Edukacja w świecie kultury popularnej, Kraków 2011, s. 7.

9 Z. Melosik, Mtodzież a przemiany kultury wspótczesnej, [w:] R. Leppert, Z. Melosik, B. Wojtasik (red.), Młodzież wobec (nie) gościnnej przyszlości, Wrocław 2005, s. 13-29.

10 A. Cybal-Michalska, Tożsamość mlodzieży w perspektywie globalnego świata. Studium socjopedagogiczne, Poznań 2006, s. 8.

OGROdY NAUK I SZTUK NR 2014 (4) 
umysłowym, doskonaleniem funkcji poznawczych oraz wzmożonego rozwoju moralnego, emocjonalnego i społecznego. Młody człowiek w okresie adolescencji eksploruje i bada otaczający go świat społeczny i samego siebie oraz zachodzące w nim zmiany fizyczne i psychiczne oraz szuka wiedzy. W trakcie takich poszukiwań młodym ludziom często towarzyszy niepokój poznawczy, poczucie zagubienia, osamotnienia i nieprzystosowania ${ }^{11}$. W czasie dorastania i dojrzewania poszukują również w literaturze wzorców i modeli do tworzenia własnej tożsamości i osobowości, pomagających w rozwiązywaniu własnych kryzysów, problemów i dylematów ${ }^{12}$. Trudno mówić o dzisiejszej młodzieży jako o jednorodnym pokoleniu, jej ideologie i światopoglądy są często skrajnie od siebie różne, dlatego też bardzo trudno dokonać charakterystyki dzisiejszej młodej generacji. Wyróżniono niedawno „Generację Y", którą określa się ludzi dorastających na przełomie wieków, korzystających masowo z nowinek technologicznych i cyfrowych. Charakteryzują się oni aktywnościa, ambicja, zdolnościami do szybkiej zmiany pracy czy miejsca zamieszkania, funkcjonują w zglobalizowanym świecie, porozumiewają się z ludźmi z całego świata, przez są bardziej tolerancyjni i otwarci. Cechują się także pewnością siebie, stawiają na jakość życia i gromadzenie wrażeń, a nie tylko posiadanie, dążą do jak najwyższego poziomu edukacji, przy czym muszą stawiać czoła coraz wyższym jej kosztom, a także są bardziej świadomi swojej wartości na rynku pracy, chcą się rozwijać i równoważyć pracę z karierą ${ }^{13}$. Przede wszystkim zatopieni są w świecie cyfrowym coraz to nowych wynalazków, które zastępują komunikację bezpośrednią. Jest to jednak jedna z wielu charakterystyk współczesnego młodego pokolenia, w którym widoczne jest także zagubienie, agresja, brak perspektyw, niechęć oraz odnawianie się ruchów nietolerancji i rasizmu. Według Krystyny Szafraniec, która prowadzi wieloletnie badania młodych pokoleń, dzisiejsza młodzież jest przede wszystkim pragmatyczna w większości dziedzin życia. Zarówno w stosunku do życia w ogóle, innych ludzi jak i wyboru szkoły, kierunku studiów, zawodu, które mają przede wszystkim przynieść zysk w postaci znalezienia dobrze płatnej pracy. Przeważa konsumpcyjne i statusowo zorientowane nastawienie, wykształcenie, praca i kariera traktowane sąjako wartości instrumentalne, mające zapewnić standard życia na odpowiednio wysokim poziomie. Młodzież ma problemy z wchodzeniem w dorosłość, często nie radzi sobie z wymogami rzeczywistości, nadmierną presją społeczeństwa i kultury na osiaganie sukcesu. Większość jednak podchodzi do tych wszystkich procesów naturalnie, podejmując wyzwania współczesności, popiera rozwiązania polityczno-gospodarcze, nie buntując się przeciw zastanej rzeczywistości, lecz szuka dla siebie miejsca w istniejących warunkach ${ }^{14}$. Obecnie młodzież nie istnieje jako kategoria podmiotowa, działająca grupa, czy siła polityczna, stanowi jedynie kategorię wiekową $a^{15}$.

\section{Kultura POPUlarna}

Kultura popularna wiązana była dotychczas raczej z upadkiem jakości kultury, jej zubożeniem oraz upraszczaniem rzeczywistości. Zaniedbywano tym samym refleksję naukową nad tym jej typem, traktując ją jako „niedojrzałą formę kultury"116 , pomijającjednocześnie rozumienie świata współczesnej młodzieży. Jednak nie należy pochopnie wartościować tego zjawiska, ale zastanowić się czy nie prowadzi po prostu, do pewnego rodzaju zmiany. Kultura popularna jest częścią otaczającej nas kulturowej rzeczywistości, obecnie już właściwie nieodłącznym elementem naszego życia, a szczególnie socjalizacji i edukacji młodych ludzi ${ }^{17}$. Warto podjąć refleksję nad tym czym jest kultura popularna, mimo że nie jest to zadanie łatwe z powodów, które wymienia m. in. Marek Krajewski. Jest to zjawisko o zróżnicowanym i wszechobecnym charakterze oraz stosunkowo nowe i trudno jest ustalić definicję ujmującą wszystkie jego aspekty i formy. Problem w konceptualizacji kultury popularnej polega również na tym, iż najczęściej nie próbuje się jej poznawać i badać, a jedynie wartościować i oceniaćc ${ }^{18}$. Popularny oznacza zrozumiały, uproszczony lub powszechny, znany, natomiast żadna z tych interpretacji nie powinna byćjednoznaczna z wartościowaniem tego zjawiska ${ }^{19}$. Genezy kultury popularnej poszukuje się w kształtowaniu się kultury masowej i powstaniem masowego społeczeństwa przemysłowego. Tym samym przeciwstawia się ją jednocześnie kulturze elitarnej, utożsamiając jej pochodzenie od kultury ludowej, która również jest zrozumiała

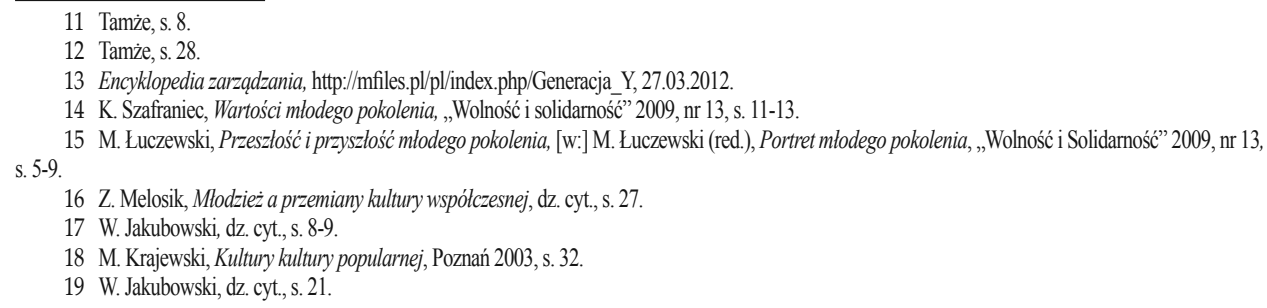


oraz łatwa w odbiorze ${ }^{20}$. Wraz z przemianami w rzeczywistości społecznej dochodzi do ukształtowania się kultury popularnej. Współczesne społeczeństwa nie są już jednak masowe, żyjemy w kulturze indywidualizmu, nie ma już kryteriów, na których można by dokonać standaryzacji odbiorców. Przyczyniła się do tego demokratyzacja i liberalizacja życia społecznego, ale także postęp technologiczny i cyfrowy, a w szczególności powstanie środków komunikacji pozwalających odbierać komunikaty i je tworzyć. Społeczeństwa przestały być homogeniczne i jednorodne, nie tworzą jednolitej masy odbiorców, czego skutkiem jest niezliczona ilość czasopism, gazet, stacji radiowych i telewizyjnych ${ }^{21}$. Bardzo dobrze ujmuje opozycję kultury elitarnej i popularnej Mirosław Gałuszka, który stwierdza, że są to dwa zupełnie różne obszary funkcjonowania i refleksji, mają inną naturę, mimo, że wchodzą we wzajemne zależności, a rozróżnienie na kulturę wyższąi popularną traci obecnie na znaczeniu. M. Gałuszka stwierdza również, że kultura popularna jest faktem społecznym wchodzącym w różne sfery życia codziennego ludzi, często wypełniającym im w całości czas wolny i jest przede wszystkim rozrywką. Najważniejsze jednak jest to, że kultura popularna jest źródłem inspiracji i identyfikacji, kreuje style życia, modę, wpływa na sposoby widzenia świata i formułowania aspiracji, zwłaszcza młodzieży².

\section{KULTURA POPULARNA JAKO MIEJSCE SOCJALIZACJI I EDUKACJI}

Socjalizacja jest to więc proces wrastania w kulturę, uczenia się i przejmowania symboli kulturowych, kształtowania się osobowości i nabywania kompetencji społecznych. Uspołecznienie może przebiegać przez zamierzone i celowe wpływy wychowawcze społeczeństwa, szczególnie tradycyjnych agend socjalizacji, ale także poprzez niezamierzony i spontaniczny wpływ środowiska społecznego, w jakim funkcjonuje dziecko. Socjalizacja dokonuje się poprzez naśladownictwo i internalizację, która jest procesem przyjmowania wzorów, norm i wartości, uznawanych jako element osobowości. Można wyróżnić dwie fazy socjalizacji: pierwotną - kiedy pod wpływem „znaczących innych”, najczęściej rodziców, nabywamy pierwszych norm i wartości społecznych stając się członkiem społeczeństwa. A także wtórna, kiedy odpowiedzialność za socjalizację przejmują takie instytucje jak: szkoła, grupy rówieśnicze, media, czy miejsce pracy. Na tym etapie dochodzi do wchodzenia jednostki w nowe role społeczne dotyczące obiektywnego świata danego społeczeństwa. Jednostka przez całe życie poprzez zachodzące interakcje uczy się wzorów kultury, w której funkcjonuje $e^{23}$. Kultura popularna ze względu na swój dominujący udział we współczesnej rzeczywistości społecznej, przez swoją wszechobecność, staje się jednym z istotnych czynników socjalizacji. Jak pisze Zbyszko Melosik „młodzież traktuje dzisiaj formalną edukację jako zło konieczne ${ }^{\prime 24}$, autorytetu nie stanowią już rodzice, nauczyciele, czy osoby z najbliższego środowiska społecznego ${ }^{25}$. Mamy do czynienia, według Margaret Mead, z kulturą prefiguratywna, kiedy to dzieci uczą rodziców. Swoje znaczenie w socjalizacji i kształtowaniu wzorów osobowych traci większość tradycyjnych instytucji socjalizacji na rzecz grupy rówieśniczej, mass mediów i kultury popularnej. Kultura popularna stała się więc miejscem, w którym młodzi ludzie nabywają wartości, normy, wzory zachowania oraz wzory osobowe, a więc naturalnym miejscem socjalizacji. Mamy do czynienia z „przesunięciem socjalizacyjnym, w którego efekcie kultura popularna stała się dziedziną pośredniczącą pomiędzy jednostka, a światem społecznym ${ }^{\prime \prime 26}$.Warto dodać, iż kultura popularna może stać się czynnikiem socjalizacji zarówno pierwotnej, jak i wtórnej. Nie powinniśmy jednak tego udziału wartościować, jest ona po prostu elementem wytworzonej rzeczywistości społecznej. Według Z. Melosika, we współczesnej zdefragmentaryzowanej, postmodernistycznej rzeczywistości wtłaczanie gotowych tradycyjnych wzorców tożsamości z obawy przed wpływem kultury popularnej i utratą własnej kontroli, może prowadzić do odebrania młodemu człowiekowi kompetencji, dzięki którym będzie sobie mógł poradzić w obecnej rzeczywistości ${ }^{27}$.

Niezależnie od oceny fenomenu kultury popularnej nie można niedoceniać ogromnego wpływu, jaki wywiera na współczesną rzeczywistość, w tym także na edukację młodego pokolenia. Pojęcie edukacji uważa się za znaczeniowo najszersze w stosunku do kształcenia i wychowania i definiuje jako ogół oddziaływań, które służą formowaniu się, czyli zmienianiu i rozwijaniu zdolności życiowych człowieka. Do ogółu oddziaływań, które wymieniane są w definicji zalicza

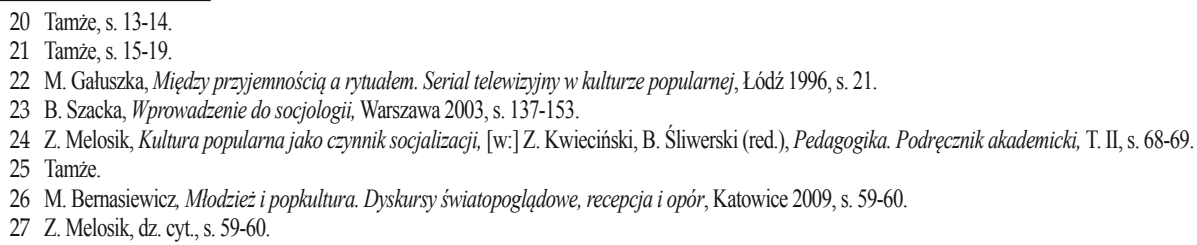


się oddziaływania instytucjonalne, indywidualne, świadome, ale też co warte jest podkreślenia - nieświadome ${ }^{28}$. Nie można zaprzeczyć już, iż żyjemy w świecie, gdzie większą część wiedzy o nim czerpiemy ze środków masowego przekazu²9. Również elementy życia codziennego zawierają treści edukacyjne, które możemy podzielić na: formalne-odbywające się poprzez tradycyjne instytucje edukacyjne i prowadzące do osiagnięcia potwierdzonych umiejętności, nieformalne - które mają miejsce obok głównego nurtu edukacyjnego, np. w miejscu pracy, w ramach działań społeczeństwa obywatelskiego, czy podczas pogłębiania zainteresowań oraz pozaformalne - które naturalnie wypływają z funkcjonowania w życiu codziennym i niekonieczne są celowe $e^{30}$. Ze względu na wspominane wcześniej: spadek oddziaływania tradycyjnych instytucji edukacyjnych oraz wzrost znaczenia nowoczesnych środków informacji i komunikacji zmniejsza się znaczenie edukacji formalnej. Edukacja nieformalna to proces przebiegający w sposób ciagły przez całe życie, $w$ którym zdobywamy wiedzę i doświadczenie, a który jest procesem nieintencjonalnym i niezorganizowanym ${ }^{31}$. Refleksja nad pozaoficjalnymi nurtami kulturowymi jest bardzo ważna, ponieważ obecnie to one mają największy wpływ na to z jakimi informacjami styka się młodzież, co myśli, a w konsekwencji jak się zachowuje. Z. Melosik pisze, iż pedagog powinien dopasować się do świata, w którym żyje młodzież, spojrzeć na świat młodych ludzi ich oczami, dowiedzieć się, co uważają za ważne i wartościowe, jakie są źródła z których czerpią wiedzę o rzeczywistości ${ }^{32}$. Potrzeba analizy kultury popularnej wypływa z jej fundamentalnego znaczenia dla kształtowania się nie tylko naszych informacji, ale też wrażeń, emocji, doświadczeń i zachowań, a które oddziałują na kształtowanie się osobowości i tożsamości. Ważne jest odnalezienie światopoglądowych treści zawartych w przekazach kultury popularnej, aby dowiedzieć się co tworzy świat, w którym żyje młodzież ${ }^{33}$.

\section{EDUKACYJNY I SOCJALIZACYJNY POTENCJAE LITERATURY}

Zawarte w literaturze treści posiadają potencjał, aby stać się a częścią procesu socjalizacji, edukacji i wychowania. Książki bowiem mogą odgrywać ogromną rolę w kształtowaniu się poglądów, systemów wartości, opinii i tożsamości kulturowej człowieka. Dzięki czytaniu, człowiek zaspokaja ciekawość poznawcza, potrzeby emocjonalne, rozwija wrażliwość i wyobraźnię oraz wyczucie na piękno języka. Książki to nieprzebrane źródło zdobywania wiadomości i doświadczeń, dzięki którym poznaje się wiele nowych światów dających możliwość różnego rodzaju przeżyć intelektualnych, moralno-społecznych, estetycznych ${ }^{34}$. „Przeżyć, jakie daje książa nic nie jest w stanie zastąić. Osobliwość kontaktu z książką polega bowiem na tym, że jest ona tylko impulsem dla ludzkiej imaginacji, bodźcem pozostawiającym naszej wyobraźni szerokie pole do własnego działania" ${ }^{135}$. Kontakt z literaturą wpływa na uczucia człowieka, pobudza zainteresowania, kształtuje aspiracje, motywacje, postawy życiowe, a poprzez to determinuje jego zachowanie. Oddziaływanie książki jest najsilniejsze w okresie formowania się przekonań i światopoglądu, wpływa ono bowiem na kształtowanie się zintegrowanych postaw sfery poznawczej, społecznej, moralnej i estetycznej. Czytanie wymaga refleksji oraz konfrontacji z przekonaniami autora tekstu, zaangażowania nie tylko intelektu, ale także uczuć i woli. Literatura wspomaga także umiejętność myślenia oraz wyrażania swoich myśli i przekonań. Umożliwia także lepsze zrozumienie własnych przeżyć oraz ich przyczyn i znalezienie rozwiązania, ale też daje szanse na wgląd w psychikę, przeżycia i emocje drugiej osoby. Poprzez emocjonalne zaangażowanie lektura może modyfikować działanie i zachowanie człowieka ${ }^{36}$. Wiek dorastania to okres intensywnego kształtowania obrazu siebie i świata, a także czas podejmowania decyzji i poszukiwania drogi życiowej. Taki okres w życiu każdego człowieka może prowadzić do kryzysu osobowości oraz do poszukiwania nowych doznań. To z jaką literaturą i jakimi książkami zetkną się młodzi ludzie, może mieć ogromny wpływ na wybór własnych wartości, własnej tożsamości oraz drogi życiowej ${ }^{37}$. Poprzez czytanie dowiadujemy się co jest ludzkie, powiększamy zakres znanych doświadczeń, co uwrażliwia spojrzenie na złożoność i wielość przeżyć i problemów ludzkich, także estetycznych ${ }^{38}$.

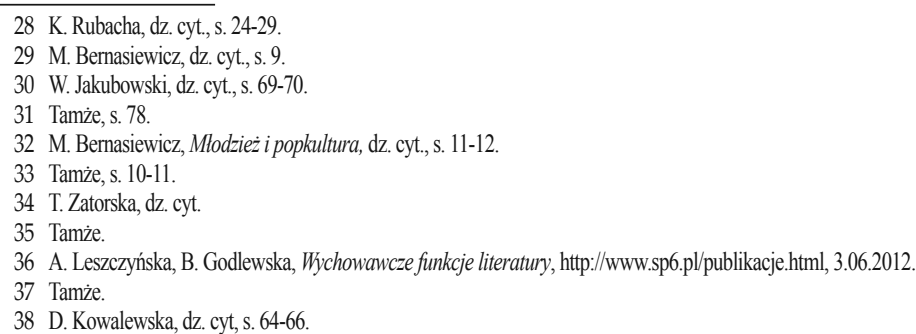


Funkcja książi nierozerwalnie związana jest z przemianami w strukturze społecznej, w obecnych czasach książka stała się jednym z wielu środków przekazu, już nie dominującym. Jej rola jest dziś inna. W zależności od przeobrażeń jakim podlega współczesne życie, przekształca się również i ona. Ciekawe spojrzenie na miejsce literatury w kulturze popularnej wskazał Piotr Kowalski, stwierdza on, iż podziały na kulturę niska, wysoka, popularnąi uczoną są obecnie raczej niejasne i intuicyjne, a o statusie literatury we współczesnej kulturze decyduje kilka istotnych kwestii. Według wielu krytyków stan kryzysowy literatury spowodowany jest zmianami cywilizacyjnymi, które poprzez popularyzację różnego rodzaju multimediów doprowadzily do spadku znaczenia książki oraz przyczyniły się do „erozji kultury literackiej”, dominującej do tej pory ${ }^{39}$. Według P. Kowalewskiego, „, komentarze do badań poziomu czytelnictwa są wyrazem bezradności badaczy, humanistów z tradycyjnym, literackim wykształceniem, uczonych, którzy tradycyjność swoich warsztatów naukowych łączą z ugruntowanymi w logocentrycznym modelu humanistyki preferencjami aksjologicznymi i oporem wobec konieczności odmiennego konceptualizowania roli i kształtu literatury"40. Przede wszystkim nowy jest sposób przekazu mediów elektronicznych, nielinearny, fragmentaryczny, który jest nieustannie konstruowany i dekonstruowany oraz generowany na nowo, łącząc w sobie wiele form przekazu, jak film, tekst, obraz, czy muzyka. W tradycyjnej literaturze można dostrzec próby dostosowania się do tych przemian, co prowadzi do powstania literatury internetowej, jako odrębnego gatunku, a nie tylko techniki przekazu, gdzie istnieje idea autorstwa otwartego, a dzieło ma otwarte zakończenie oraz gdzie istnieje multimedialnie, wzbogacone obrazami, muzyką i filmikami. Skutek tych okoliczności jest taki, że socjalizacja do kultury odbywa się poprzez nowe media i ma charakter multimedialny i chociaż literatura jest wciąż formalnie konserwatywna, to zmieniają się kompetencje odbioru młodych uczestników kultury. Kryzys literatury ma swoje źródła w dominacji mediów wymagających mniejszego wysiłku, a które operują jednym tekstem w wielu formach przekazu i tak dokonuje się ekranizacji dzieła literackiego, przekład na komiks, tworzona jest gra komputerowa, tak powstaje tekst nowej generacji, który traci wiele znaczeń ze swojej pierwotnej wersji, zyskuje jednak wiele nowych ${ }^{41}$.

Powieści bestsellerowe, najpopularniejsze, rozchwytywane, sprzedające się w tysiącach egzemplarzach, czytane przez młodzież, które najczęściej są równocześnie powieściami młodzieżowymi, często spotykają się ze sceptycznym odbiorem krytyków literackich i dużej części społeczeństwa. Takie fenomeny popularności czytelniczej w czasach, w których aktywność czytelnicza zanika na rzecz różnego rodzaju mediów, szczególnie wśród młodzieży wywołują zastanowienie. Jaka jest przyczyna sukcesu i popularności takich książek jak Harry Potter, Zmierzch, czy Igrzyska Śmierci. Szczególnie popularne są także powieści fantasy. Tego typu literatura spotyka się często z zarzutem, iż masowa jej sprzedaż nie stanowi o jej wartości artystycznej, ale jest wynikiem szeroko zakrojonych akcji marketingowych. Literaturze młodzieżowej, która często zawiera elementy fantastyki i magii zarzuca się, iż może ona zawierać nieodpowiednie, czy wręcz szkodliwe treści dla młodzieży, kształtującej dopiero swoją tożsamość, a także wywoływać chęć ucieczki od rzeczywistych problemów, czy sprzyjać braku rozróżnienia między fantazja, a rzeczywistością. Równie istotne jest pytanie o wartości edukacyjne powieści dla młodzieży. Wobec literatury pięknej formowane są bowiem oczekiwania, iż jej oddziaływanie będzie miało charakter wychowawczy oraz rozwojowy ${ }^{42}$. Sztuka relacji z zainteresowaniami literackimi młodych ludzi, polega na spotkaniu się w pół drogi miedzy światem młodzieży, a światem dorosłych oraz otwartym i pełnym szacunku towarzyszeniu młodemu czytelnikowi w jego drodze do oswojenia lęków, poznania tego, co dotychczas nieznane, wprowadzenia go w rzeczywistość wymagającą wielkiej wiary, sily charakteru, dojrzałości i odporności psychicznej ${ }^{-43}$.

\section{CZYTELNiCY MAŁOMIASTECZKOWI}

Badania stanowiące podstawę artykułu zostały przeprowadzone z młodymi ludźmi pochodzącymi z małego miasta, liczącego mniej niż piętnaście tysięcy mieszkańców. Zofia Zasadzka w swoich badaniach, które były prowadzane na terenie całej Polski wyodrębnia cechy charakterystyczne czytelników pochodzących z różnej wielkości miejscowości, również kategorię czytelników małomiasteczkowych. Jak się okazuje, kategoria ta posiada cechy szczególne, przede wszystkim ich wybory są tradycyjne, co oznacza iż młodzież czyta mniej literatury fantasy i sensacyjnej, a więcej literatury pięknej i obyczajowej, szczególnie tej przeznaczonej dla młodzieży. Najważniejszy jest etyczny aspekt lektury, najchętniej czytane są książki z morałem, podające wzory postępowania i stanowiące wskazówki w dylematach egzystencjalnych. Dominujące

39 P. Kowalski, dz. cyt., s. 123

40 Tamże, s. 124.

41 Tamże, s. 123-130.

42 D. Kowalewska, dz. cyt., s. 8-12

43 Tamże, s. 12. 
jest także w tej kategorii pragmatyczne podejście do czytania, ceniony jest realizm w wybieranych pozycjach. Najrzadziej mieszkańcy małych miast czytali literaturę popularnonaukową oraz fantastyczną. Dziewczęta są aktywnymi czytelniczkami powieści dla dziewcząt, a chłopcy najchętniej czytają prasę sportową i są kibicami programów sportowych. Jeżeli chodzi o zaopatrywanie się w książki, to tendencje w małym mieście są przeciwstawne wobec stylu wielkomiejskiego, młodzi ludzie chętniej w porównaniu do innych korzystają z bibliotek publicznych, najrzadziej natomiast z bibliotek domowych, równie rzadko kupują książki ${ }^{44}$.

\section{WYNIKI BADAŃ PRZEPROWADZONYCH Z MŁODZIEŻĄ LICEALNĄ}

Głównym celem moich badań było określenie fascynacji literackich młodego pokolenia w kontekście edukacyjnego oraz socjalizacyjnego wpływu kultury popularnej, na podstawie wypowiedzi uczniów chojnowskiego liceum ogólnokształcącego. Badania o charakterze jakościowym zostały przeprowadzone za pomocą wywiadu ukierunkowanego, który pozwolił dotrzeć do informacji stanowiących odpowiedź na cel i problematykę badań. W badaniach wzięło udział piętnaścioro młodych respondentów. O udział zostały poproszone zarówno osoby, które stwierdziły, iż posiadają zainteresowania literackie oraz takie, które deklaruja, iż raczej książek nie czytają. Problemy szczegółowe, które zostały postawione w badaniach zawierają się w kilku zgrupowanych pytaniach badawczych:

Czy licealiści czytają książki? Jaki jest poziom aktywności czytelniczej młodych ludzi i jakie są przyczyny ich zachowania? W jaki sposób czytają młodzi ludzie?

Jakie preferencje czytelnicze posiadają badani? Jakie rodzaje i typy literatury są wybierane przez adolescentów, do jakich tytułów sięgająi czy są one związane z kulturą popularną?

Jakie są motywy sięgania do literatury? Dlaczego młodzi ludzie sięgają po książki, szczególnie w czasach dominacji wszelkiej technologii elektronicznej. Jakie wzory kultury czytelniczej wynieśli z domu?

Jakie role i funkcje spełnia literatura i książka w życiu młodych ludzi? Czy czytanie jest dla nich wartościa, czego szukają w literaturze, co jest dla nich najważniejsze?

\section{"CZYTAJĄ TYLKo NIELICZNI"}

Charakterystyczne dla większości młodych ludzi, którzy wzięli udział w badaniach, jest zgeneralizowane przekonanie, że większość ich rówieśników nie czyta książek lub czyta ich bardzo mało, zarówno jeżeli chodzi o książki papierowe, jak i książki we wszystkich innych formach. Co więcej nie są oni właściwie w stanie ocenić, jak wygląda poziom czytelnictwa w ich najbliższym otoczeniu ze względu na to, iż nie jest to ważny element ich relacji rówieśniczych, a czasem zwyczajnie o literaturze i książkach nie rozmawiają. Dobrze odzwierciedlają to poniże wypowiedzi:

W sumie nie wiem, nie rozmawiam ze znajomymi o czytaniu za bardzo, także nie wiem za bardzo co czytaja. Wiem, że moje koleżanki czytają Zmierzch. (Martyna)

Zwłaszcza na polskim przed lektura, czy przeczytałeś, czy coś, a tak to raczej nie. (Paulina)

Niemal wszyscy badani licealiści zgodnie twierdza, że osób czytających książki jest niewiele. Należy jednak pamiętać, iż są to jedynie powierzchowne obserwacje, często młodzi ludzie także nie potrafią podać przyczyn takiej sytuacji, możliwe jest, iż nie zastanawiali się wcześniej nad tym zjawiskiem. Jak w wypowiedzi jednej z badanych:

Niewiele osób czy ta ksiażki, mam tam kilka koleżanek, ale to sa nieliczni naprawdę. No niewiele osób czyta ksiązi i z tego co wiem, z tych osób, które znam, to będzie kilka osób, takich, że czytają dla fascynacji. (Ewa)

Osoby, które zauważają przyczyny braku sięgania do literatury, twierdza, iż ich rówieśnicy większość czasu spędzają w Internecie, wolą oglądać filmy lub nie męczyć się i obejrzeć ekranizację lub adaptację filmową oraz iż posługują się streszczeniami, ze względu na to, że szkoda im czasu na czytanie. Według badanych licealistów czas wolny ich rówieśników zdominowany jest przez media, traktowane jako prostsze rozrywki, równocześnie czytanie kojarzone jest z dużym wysiłkiem. Potwierdza to spostrzeżenia zawarte we wcześniejszej części artykułu, mówiące o tym, iż odczytanie kodu literackiego w tradycyjnym rozumienia nastręcza dzisiaj wiele trudności młodym ludziom.

komputer przeważa teraz, szukają najprostszej rozrywwi. Prościej zagrać, mieć wszzystko na tacy niż sięgnać do książi, niż samemu wyjmować, treść. (Wojtek)

Bardzo ciekawa jest wypowiedź jednej z dziewcząt, która pokazuje powszechnie panująca opinię, przyjmowaną już

44 Z. Zasadzka, Nastoletni czytelnicy, Warszawa 2008, s. 180-181.

45 Cytat $\mathrm{z}$ wypowiedzi jednej z uczestniczek pochodzący z badań własnych. 
chyba stereotypowo, bez zastanowienia przez kolejne generacje, stwierdzające, że im młodsze pokolenie, tym mniej osób czytających książki.

Zawsze się znajda zwolennicy ksiązek. Jeszcze ma znaczenie, ale już w młodszych pokoleniach, co chodza do gimnazjum, to już bardziej facebook i komputer. (Ola)

Wypowiedzi licealistów, dotyczące ich własnej aktywności czytelniczej, przedstawiają nieco bardziej optymistyczny obraz stanu czytelnictwa młodzieży. Wśród osób, które wzięły udział w badaniach można wyróżnić trzy główne kategorie czytelników.

Osoby czytające regularnie, dość często, nawet codziennie, lubią czytać, stanowi to ich pasję, odczuwają potrzebę czytania, a przede wszystkim ją realizują. Jest to stosunkowo nieliczna grupa i można było do niej zaliczyćjedynie dziewczęta. Reprezentatywna dla tej grupy jest wypowiedź jednej z licealistek:

Czytam ksiazki. Staram sie jak najwięcej, tylko że nie zawusze jest czas, bo wiadomo szkota. Teraz akurat to nie za bardzo, tak jedynie to lektury i to też tak z grubsza, powierzchownie. A tak jak jest czas, to staram się jak najwięcej. Ostatnio na feriach przeczytałam chyba pięć ksiażè i to też pracowatam, także... Byty dwa tygodnie, no to troszkę mi się udało nadrobić. Wcześniej jak bytam w gimnazjum to byto tego czytania więcej, bo nie byto tyle nauki, a teraz to jednak nuka ważniejsza. (Ania)

Osoby, które rzadko lub od czasu do czasu czytają książi, traktują czytanie jak jedną z wielu form rozrywki, ale dostrzegają znaczenie i wartość książek, częściej podkreślają także instrumentalną funkcję książki, jak np. pomoc w rozwoju słownictwa i ortografii. Większość osób przypisuje różne wartości czytaniu, ale niewiele z nich książki czytuje lub robią to dość rzadko. Jak widać w wypowiedzi jednego z badanych:

Czytam, ostatnio muszę przyznać że komputer przeważa, ale średnio raz na dwo miesiace przeczytam coś konkretnego. Po prostu zainteresuje mnie tematyka ksiażki.(...) Po pierwsze chcę zabić czas, po drugie czasami potrzebuję czegos do rozmyślenia, lubię pomyśleć nad ksiażka. [czytanie] kształtuje poglady, ale ja to głównie traktuje jako taką rozrywkę. (Wojtek)

Ostatnią grupę natomiast stanowią młodzi ludzie, którzy w ogóle nie czytają książek, nie czują takiej potrzeby, jest to dla nich czynność nużąca, która nie jest im niezbędna. Nie przypisują czytaniu jakiejś szczególniej wartości, sami praktycznie nie sięgają do książek.

Nie czytam, nie chce mi się, wole tak bardziej filmy, np. jak są ksiażki przełożone na filmy, ale tak, żeby czytać to nie, nie lubię po prostu czytać. Nudza mnie szybko inie chciałoby mi się zaczynać nawet. Najczęściej w wohnym czasie spotykam się ze znajomymi iśsię. Mało ludzi czyta ksiażki, bo są ksiażki przetożone na filmy i wola obejrzé film, niż się męczyć z przeczytaniem. (Ala)

Powodów, dla których licealiści czytają książki jest wiele, najczęstsze przyczyny dla których młodzi ludzie sięgają do literatury to potrzeba oderwania się od rzeczywistości, ucieczki od otaczającego ich świata. Ponadto młodzież odczuwa potrzebę utożsamienia się z bohaterem literackim i jego problemami oraz pomocy w rozwiązaniu własnych trudności. Postrzega także literaturę jako źródło rozwoju i kształtowania osobowości oraz możliwość lepszego zrozumienia rzeczywistości, dla młodzieży najważniejsza jest eskapistyczna funkcja literatury oraz pomoc jaką ona niesie dla zrozumienia rzeczywistości i istniejących w niej problemów, z którymi musi mierzyć się młody człowiek. Interesujące jest, iż młodzi ludzie bardzo często podkreślają wyraźnie instrumentalną funkcję książek, które głównie mają pomóc w rozwoju poznawczym, wzbogacić słownictwo, lepiej zapamiętać zasady ortograficzne, ale też zdobyć potrzebną wiedzę. Czytanie według licealistów poszerza horyzonty myślowe i światopogląd oraz rozwija wyobraźnię i dostarcza wiedzy w zakresie stanowiącym pasję lub hobby.

[Czytanie] (...) jest ważne na pewno, sam to zauważytem na własnym przyktadzie mogę podać, że znacznie wzbogaca słownictwo. Czytam regularnie no i w porównaniu np. do kolegów którzy nie czytają wypowiadam się o wiele lepiej, wzbogacają me stownictwo i poszerzają światopoglad.(Wojtek)

Główne przyczyny braku sięgania po książki podawane przez licealistów pokrywają się z ich ogólnymi spostrzeżeniami dotyczącymi zachowań rówieśników. Licealiści przyznaja, ze głównymi powodami braku czytania jest dominacja w ich życiu różnych mediów, a szczególnie komputera i Internetu. Młodzi ludzie twierdzą także, iż wolą wybrać łatwiejszy sposób na zapoznanie się z książka, jak przeczytanie streszczenia, czy zobaczenie filmu. Do czytania zniechęca także przymus czytania lektur, część badanych podkreśla także, że nie lubi czytać, a literatura nie leży w ich kręgu zainteresowania, obcowanie z tekstem jest zbyt nużące i zniechęcające. Jak wynika z wypowiedzi licealistów, większość z nich nie lubi czytać lektur, najczęściej posługują się streszczeniami. Powodem rzadkiego sięgania do książek według młodzieży jest także duża ilość obowiązków oraz brak czasu spowodowany głównie dużą ilością czasu poświęcanego na naukę.

Zdecydowanie bo im się nie chce, wola np. posiedzié sobie na Internecie, przeczytać sobie streszczenie, krócej spędzić czas nad tym, niż siedzieć i czytać cała ksiażkę. Wola przeczytać streszczenie, lektury sa nudne i większość osób wręcz nie chce tego czytać. Po

OgROdY NAUK I SZTUK NR 2014 (4) 
prostu im się nie chce, są nudne, zbyt nudne, można zasnać jak się czyta taką lekturę. Nie czytam, wole streszczenia niż lektury. (Ala)

Badania zostały zaplanowane z uczniami liceum ogólnokształcącego, ponieważ w założeniu teoretycznym są to osoby, które przygotowywane są do matury oraz do studiów akademickich, polegających w większości na pracy z tekstem. W trakcie kształcenia w szkole średniej uczniowie powinni zdobyć wiedzę ogólną i zostać zaznajomieni z kulturą literackă wykazując także samodzielne zainteresowanie literaturą i czytelnictwem. Teoretycznym założeniem jest również, iż osoby które pragnęły kontynuować edukację przygotowującą do studiów wybrały liceum, a pozostałe osoby inne szkoły np. techniczne, powinny więc wykazywać chęć kontaktu z kulturą literacką oraz własne zainteresowania literackie. Tym bardziej warto przyglądać się licealistom, ich stosunkowi do literatury i świata tekstu, szczególnie iż stanowią oni większość w stosunku do uczniów innego typu szkół średnich ${ }^{46}$.

Można zgodzić się z opinią młodych ludzi, iż nieliczne osoby są stałymi czytelnikami, odczuwającymi potrzebę kontaktu z literatura, chociaż większość osób dostrzega wartości jakie ona niesie dla rozwoju różnych sfer funkcjonowania człowieka. Można dostrzec wyraźnie rozbieżności między wartościami uznawanymi, a praktykowanymi. Chociaż młodzi ludzie przyznaja, że sięgają do książek, nie potrafią często podać czytanych przez siebie autorów, czy tytułów, równie często nie są w stanie podać książi ulubionej lub szczególnie dla nich ważnej, nie posiadają także głębszych refleksji na temat swojej aktywności czytelniczej. Stwierdzić można, iż są raczej powierzchownymi czytelnikami, istnieją jednak pewne osoby, które dokładnie wiedzą jakimi są czytelnikami oraz co ich interesuje.

\section{„ŻYYCIE JEST CIEKAWSZE JAK SIĘ CZYTA KSIĄŻKI" "t?}

Należy zastanowić się, czy książka stanowi w odczuciu nastolatków część ich świata, czy książki wspóttworzą ich świat wewnętrzny, psychologiczny, czy stanowią ważny jego element, czy pojawiają się w sytuacjach komunikacyjnych. Rozmowy z młodzieżą ujawniły niezmiernie ciekawy stosunek do książek, który można dostrzec wyraźnie w niektórych wypowiedziach, ale jest tez obecny jako milczące założenie w innych. Według mojej interpretacji, młodzi ludzie nie uważają książek za część swojego codziennego świata, oczywiście są wyjątki w postaci całkiem aktywnych czytelników, jednak są to tylko wyjątki. Czytanie traktują jako powrót do tradycji, w ich codziennym funkcjonowaniu, parafrazując wypowiedź jednej z dziewcząt, to komputer wypiera czytanie książek, a młodzi ludzie prowadzą walkę ze sobą o powrót do aktywnego czytania.

Myśle, że [czytanie] ma znaczenie bo o tym się zapomina, to jest jakiś powrót do tradycii, nie wiem jak trzymam starsza ksiażke, starsze woydanie to czuje się czéścią przesztości. (Martyna)

Jest dla mnie ważne czytanie i na pewno jest to jakaś tam cześśc mojego życia, ale ostatnio zauważyłam, że komputer wypiera u mnie czytane. Powoli jakby zaczynam mieć ważniejsze sprawy niż czytanie, aczkolwiek staram sie jakoś jeszcze czytać, bo wiem, ze to rozwija mój umyst i mój charakter. (Ania)

Świat młodych ludzi opiera się na funkcjonowaniu i komunikacji poprzez mass media, ich czas wolny według nich samych zdominowany jest przez Internet, książki są jedynie gośćmi w ich codziennej rzeczywistości. „Książka znajduje się dzisiaj w sytuacji koegzystencji komunikacyjnej” Wraz z innymi środkami przekazu „współtworzy obraz kultury (...) wypełniony z jednej strony kulturą druku, a z drugiej kulturą elektroniczną ${ }^{\prime \prime 48}$, pisze autorka artykułu dotyczącego literatury elektronicznej i dodaje, iż istnieje nadzieja, że dzięki zaawansowanym technologiom informacyjnym uda się na nowo rozbudzić potrzebę czytania w naszym społeczeństwie. Jednak nie można tego dostrzec w wypowiedziach chojnowskiej młodzieży licealnej. Żadna z badanych osób nie stwierdziła, że korzysta z literatury w formie cyfrowej, czy z jakichkolwiek czytników elektronicznych. Nie korzystanie z elektronicznych form literatury, uzasadniane jest najczesściej szkodliwością spędzania długiego czasu przed ekranem komputera, co stanowi sprzeczność wobec wcześniejszych wypowiedzi o tym, iż komputer przeważa nad czytaniem w wyborach młodych ludzi. Świat młodzieży z małego miasta nie jest światem tekstu, ma niewielki związek z komunikacją na poziomie tekstu. Co więcej, przerażający jest fakt, iż sami licealiści, nawet $\mathrm{Ci}$ od czasu do czasu sięgający po lekturę twierdza, iż nie rozmawiają z rówieśnikami o książkach.

Tylko nieliczne osoby stwierdziły, że ich stosunek do literatury i samej ksiązi jest wyjątkowy, a książki stanowią ważną część ich życia, uwielbiają książki kupować oraz kolekcjonować. Lubią książki jako przedmioty, cieszy je kontakt z nimi. Można wnioskować, iż emocjonalnie podchodzą do kontaktu z książką. Wykazują także własne upodobnia i wy-

\footnotetext{
46 Mały Rocznik Statystyczny Polski 2013, www.stat.gov.pl, 20.05.2012, s. 243.

47 Cytat z wypowiedzi jednej z uczestniczek pochodzący z badań własnych.

48 J.Ziaja, Literatura elektroniczna a czytelnictwo mlodzieży akademickiej, ,Podkarpackie Studia Biblioteczne”2012, nr 1, http://psb.univ.rzeszow.pl/sites defaultffiles/pdf/literatura elektroniczna a czytelnictwo mlodziezy akademickiej.pdf, 27.04.2013., s. 2
} 
bory literackie, nie mają problemu ze wskazaniem ulubionej pozycji literackiej, czy najczęściej czytanego autora. Żywiołowo opowiadają o książkach, które były dla nich ważne, przełomowe, zmieniły coś w ich życiu, czy skłoniły do refleksji lub zmiany perspektywy życiowej. Taki stosunek można dostrzec w poniższej wypowiedzi:

Jest dla mnie ważna ksiażka, ogólnie to lubię kupować ksiażki, to chyba nawet jestem uzależniona, lubię mieć je wo szafie, kiedyś chciałam mieć wotasną bibliotekę w domu, tzn. dalej chce miéc i lubie jak one są w szafie, chociaż jak już je przeczytałam, to jakoś ciężko mi jest się z nimi rozstać. Jeżeli chodzi o sam przedmiot ksiażkę, to jest dla mnie bardzo ważna, i nie lubię form, elektronicznych, po prostu tego nie czuje tego nie moga dotkną́, jednak jak mam ksiażkę w ręku to inaczej jest, inaczej sie ją czyta. (Ania)

Większośćlicealistów, mimo tego że dostrzega wartość literatury, to nie sięga do niej zbyt często, posiada do niej stosunek obojętny. Istnieje również grupa osób, która nie czyta książek wcale, uważając je za nudne, niepotrzebne, nie mogące nic w ich życiu zmienić.

Wybory literackie młodziėzy z Chojnowa upodobniają się do wyborów osób zamieszkujących w dużych miastach, co może wskazywać na homogenizację upodobań literackich i wyborów kulturowych młodzieży ${ }^{49}$. Potwierdza to teorię o specyficzności kategorii młodzieży, według której obecni młodzi ludzie na całym świecie upodabniają się do siebie. Poprzez oddziaływanie globalizacji, wpływ mass mediów, komunikaty kultury popularnej, które są niemalże identyczne na całym świecie, młodzi ludzie funkcjonują w podobnej rzeczywistości medialnej, która kształtuje ich zainteresowania, wartości i wybory kulturalne, a więc również literackie. Badani licealiści zanurzeni są w większości w literaturze popularnej. Bardzo dobrze oddaje to wypowiedź jednej z dziewcząt, która twierdzi, iż jest dość aktywnym czytelnikiem, jednocześnie ksiązi, które wskazuje należą jedynie do najmodniejszych i najpopularniejszych pozycji młodzieżowych.

Najchętniej, ooólnie czytam młodzieżowe ksiażki takie bardziej, lubię fantasy bardzo, jakiés thrillery też czasami, a czasami po prostu jakiés powiésci. Saga Harry Potter, też jest taka saga Percy Jackson i Bogowie Olimpijscy, tak związane z mitologia także lubię. Też jest taka saga Igrzyska Śmierci, też przeczytałam wszystkie ksiażki, Wtadca Pierścieni. Myśle, ze fantasy takie mnie jakós zaciekawia, ciekawie się czyta i tak szybko fajnie się czyta (...). (Ola)

Osoby, które sięgają po książki, najchętniej czytają literaturę fantasy, powieści obyczajowe z wątkami miłosnymi, szczególnie dziewczęta oraz najpoczytniejsze bestsellery literatury młodzieżowej. Książki, które według licealistów popularne są wśród ich rówieśników, należą najczęściej do kręgu literatury popularnej: saga Zmierzch Stephenie Mayer, Harry Potter Joanne K. Rowling, trylogia Wtadca Pierścieni Johna R. R. Tolkiena. Dużym zainteresowaniem wśród badanej młodzieży cieszą się powieści Nicholasa Sparksa, wiele z nich podawanych jest jako książki szczególnie ważne, znaczące, czy takie, które spowodowały chęć dalszego sięgania po lekturę. Niektóre osoby zaskakują podając książki szczególnie dla nich znaczące, bowiem obok znanych popularnych tytułów znalazły się także: Myśli nowoczesnego Polaka Romana Dmowskiego, czy Duma i Uprzedzenie Jane Austin. Wielu licealistów, którzy wzięli udział w badaniach posiadało duże trudności z podaniem książki szczególnie dla nich ważnej, takiej która miała wpływ na ich życie, czy postępowanie. Trudności pojawiały się także ze wskazaniem ulubionej książki z dzieciństwa, chociaż większość osób stwierdziło, iż rodzice czytali im w dzieciństwie, to często nie pamiętają żadnego tytułu. Kilka osób jednak wymieniła książki, które darzyli oni szczególną sympatiąjako dzieci, należą do nich: Ulice Strachu, Karolcia, Koziołek Matołek, czy Przygody Mikołajka. Młodzi ludzie w większości nie potrafią także uzasadnić dlaczego sięgają do określonego typu literatury, ich wybory rzadko są więc świadome i uporządkowane, jest to raczej poszukiwanie charakterystyczne dla młodzieńczego okresu życia, ale przede wszystkim brak wiedzy dotyczącej literatury oraz brak chęci i potrzeby sięgania do literatury, co dobrze charakteryzuje wypowiedź:

A to z różnej palety, raz z romantyzmu, np. Byrona, tak Byrona czytatem sporo, tak to jeszcze nie dokończylem czytam sobie Potege Podświadomości, no mówwę, tak z różnej palety wybieram sobie, to na co mam ochotę. Żeby wzbogacić stownictwo i generalnie w tym przypadku, żeby poszerzyć światopoglad. Czy masz jakieśs ulubione ksiażki. Generalnie nie, w zależy od mojego natchnienia, jeżeli mam akurat ochote przeczytać, to przeczytam, nie mam ulubionej. Potęga podśswiadomości, dzięki niej tak sobie teraz pozytywnie myśle, jestem pozytywnie nastawiony na świat, żeby jakoś tak przeboléc niektóre sprawy. (Dawid)

Z tego też względu, pozycje książkowe które są najczęściej czytane należą do najpopularniejszych cyklów powieściowych dla młodzieży. Osoby czytające uzasadniają swoje upodobania literackie chęcią oderwania się od rzeczywistości, ucieczką w inny świat, poszukiwaniem refleksji, własnej tożsamości, ale też chęcią wzbogacenia słownictwa. Tylko w jednym przypadku można było dostrzec wyraźnie świadome podejście do własnych zainteresowań literackich i świadomy wybór lektury:

Lubię powieści Jane Austin, kobiece, to sa moje ulubione tak naprawdę, oprócz tego jeszcze Lwa Totstoja lubię Wojnę i pokój, to już

49 Z. Zasacka, dz. cyt., s. 169-181.

OGRODY NAUK I SZTUK NR 2014 (4) 
takie historyczne bardziej, chociaż np. Anna Karenina, to już takie psychologiczne też. No i oczywiście Tolkiena fantasy, to wiadomo Wtadca Pierścieni, czasem przeczytam ksiażki popularno naukowe, też się zdarzy. Ponieważ najbardziej mnie ciekawi, po prostu są tam, te zagadnie psychologiczne i bardziej mnie to interesuje, niż miałabym wziać jakaśs ksiażkę dla nastolatków i ją czytać, dla mnie nie jest ważne wydarzenie, tylko osoba, która jest w ksiażce i co ona tam poczynia. Na perwno Duma i uprzedzenie Jane Austin, bo tam można spotkać takie żartobliwe sytuacje, które w dawnych czasach miahy miejsce, a teraz w tych czasach można znaleźć odzwierciedlenie tych sytuacji i to jest dla mnie takie fascynujace. Oprócz tego Wtadca Pierścieni, a to dlatego, że bardzo tadne sa opisy krajobrazu i wiersze, a ja lubię wiersze czytać. Rodzice też mi czytali wiersze i jakoś to tak się we mnie zakorzenito. (Ania)

Można więc zgodzić się z badaczami kultury popularnej, mimo że dotychczas była ona wiązana raczej z upadkiem jakości kultury i jej uproszczeniem, ma ona ogromne oddziaływanie na młodego odbiorcę. Większość sfer naszego funkcjonowania związanych jest dzisiaj z kulturą popularna, oddziaływującą na nas poprzez wiele kanałów komunikacyjnych jednocześnie i nieustannie. Dostrzegamy więc wyraźną zmianę w dzisiejszej kulturze, która najlepiej uwidacznia się w zainteresowaniach i zachowaniach młodych ludzi, obserwując których można jak w soczewce dostrzec wszelkie oznaki przemian społecznych i kulturowych. Kultura i literatura popularna są dziś miejscem socjalizacji i edukacji o szczególnym wpływie na postawy, myślenie, i zachowanie młodych ludzi. W świecie fast $(f \circ o d, s e x, c a r)^{50}$, coraz mniejszym zainteresowaniem cieszą się tradycyjne powieści, klasyka literatury, wymagające dużego wysiłku, pogłębionej refleksji i sporej ilości czasu oraz przede wszystkim skupienia, co stanowi pewien problem w postmodernistycznych czasach hipertekstu.

\section{„TAK NAPRAWDĘ PRZEZ KSIĄŻKĘ MOGĄ POZNAĆ ŻYCIE" ${ }^{\text {"51 }}$}

Najczęściej wymienianym i chyba najważniejszym powodem sięgania do literatury, a szczególnie literatury fantasy i gatunków pokrewnych, jest chęć oderwania się od rzeczywistości, czy wręcz ucieczki od świata, w którym się funkcjonuje oraz od problemów i zmartwień towarzyszących codzienności. Motyw ten przejawia się właściwie w każdej wypowiedzi, co obrazuje poniższy cytat:

Czytam ksiażki, to jest takie oderwanie od rzeczywistości jak dla mnie mogę zapomniéc o swoich problemach, lubię przeżywać to co przė̇ywają bohaterowie ksiażek. Ja głównie szukam głównie takiego oderwania, że ja mogę przeżywać te przygody, które bohaterowie przeżywają i zapominać o świecie, lubię się tak oderwać i zapomnieć o wszystkim. (Ewa)

Licealiści najczęściej poszukują innego, ciekawego świata, zupełnie odmiennego od realiów, w których funkcjonuja. Literatura w tym przypadku pełni wobec nich funkcję eskapistyczna, środka ucieczki przed rzeczywistością oraz źródła schronienia, wydaje się, że jest to obecnie najważniejsza funkcja książki dla młodych ludzi. Potrzeba ucieczki w inny świat, oderwania od rzeczywistości, znalezienia czegoś innego, jak np. w wypadku takiej wypowiedzi:

Nie wiem, jakiejśs fantazji, czeeoś czego co tutaj niema, czegoś ciekawego. (Magda)

Może być ona wyrazem zniechęcenia do otaczającego świata. Rzeczywistość w jakiej funkcjonują młodzi ludzie nie zaspakaja ich potrzeb, rozbudzanych jeszcze przez konsumpcjonizm napędzany kulturą popularną. Literatura w takim wypadku spełnia funkcję substytutywną lub kompensacyjna, która ma za zadanie przez identyfikację z bohaterami i przedstawiony świat literacki rozładować napięcia i lęki, zastąpić niechcianą rzeczywistość światem fikcyjnym. Może także służyć rekompensowaniu samotności lub zastępowaniu najbliższych osób, osobami fikcyjnymi, aby uzyskać poczucie przynależności społecznej. Badani licealiści odczuwają przede wszystkim chęć zapomnienia o realnym świcie, literatura daje im świat iluzji, w którym mogą na chwilę zapomnieć o troskach dnia codziennego. Kolejną motywacją sięgania do książek jest potrzeba wiedzy, potrzeba materiału do rozmyślań i refleksji, kształtowanie światopoglądu, spojrzenie na świat z innego punktu widzenia, zdobycie nowych informacji, które kształtują człowieka i jego osobowość, uzyskania informacji dotyczącego zainteresowań i hobby, wiedzy o świecie. Podkreślają również znaczenie czytania dla rozwoju wyobraźni.

Z moich ogólmych spostrzeżé stwierdzam, że ludzie którzy czytają ksiażki sa znacznie madrzejsi od tych którzy nie czytaja. Moga dać wiedzę, bardzo duża wiedzę i umiejętność wyrażania się. (Marta)

Bardzo ważna jest więc funkcja poznawcza literatury oraz wspomniana wcześniej funkcja instrumentalna. Młodzi ludzie uważają książkę za pewne źródło informacji, w przeciwieństwie do Internetu, w którym można znaleźć wiele różnych informacji, nie znając ich źródła pochodzenia. Mimo tego twierdzą również, iż książi tracą swoje znaczenie w dzisiejszym świecie na rzecz Internetu i tym samym możliwości szybkiego zdobycia informacji.

Zawsze miało ibędzie miato znaczenie [czytanie]. Czy obecnie może mniej, no bo z tekstami spotykamy się na co dzień w Internecie w gazetach, trzeba przyznać że Internet też tam teraz się ksiązek dużo czyta. Jakby nie patrzé książa to zawsze takie pewone źródto,

50 Z. Melosik, Młodzież a przemiany kultury wspótczesnej, dz. cyt., s. 13-29.

51 Cytat $\mathrm{z}$ wypowiedzi jednej z uczestniczek pochodzący z badań własnych. 
które nigdy nas nie zawiedzie. (Wojtek)

Młodzi ludzie szukają w literaturze także przeżyć emocjonalnych, czytanie silnie angażuje nasze emocje oraz wyzwala całe ich spektrum. Czytanie daje szanse na przyjrzenie się psychice innej osoby, jej emocjom, przez co możliwe jest poznanie własnych przeżyć, poznanie ich przyczyn i lepsze zrozumienie. Pozwala na uporządkowanie własnych przeżyć oraz lepsze, pozwalające na odpowiednie kształtowanie tożsamości. Identyfikacja z bohaterem, silne emocjonalne zaangażowanie może wpływać nawet na zmianę sposobu myślenia i zachowania człowieka. Dla licealistów bardzo ważnym motywem sięgania do literatury jest możliwość identyfikacji z bohaterem, który jest do nich podobny, spotyka się z takimi samymi problemami, przeżywa podobne trudności i sytuacje.

Czytam, bo pozwala mi się to tak oderwać od rzeczywistości, skupić się przez jakạś chwile na czymśs innym, utożsamić się może z bohaterem, albo z jakimiś problemami, które sa w perwnym stopniu powiązane ze mna. (Agnieszka)

Ujawnia się w przypadku funkcji emocjonalnej literatury różnica między chłopcami i dziewczętami. Wątków miłosnych, romantycznych, opisów związków i relacji pomiędzy ludźmi szukają przede wszystkim dziewczęta. Wypowiedzi licealistów uwidaczniają charakterystyczną dla wieku młodzieńczego potrzebę poszukiwań dróg do zrozumienia siebie, świata oraz innych ludzi, ich postępowania i emocji. Potrzebę kształtowania swojej tożsamości, poprzez obserwację przeżyć własnych i innych ludzi ${ }^{52}$. Literatura spełnia więc $\mathrm{w}$ życiu młodzieży także funkcję emocjonalna, jest jednocześnie źródłem przeżyć oraz wiedzy o nich, pomaga w zrozumieniu swojego życia uczuciowego i w kształtowaniu swojej osobowości, literatura pełni więc również rolę terapeutyczną.

Mam inne patrzenie na świat przede wszystkim po takich ksiażkach dużo więcej rzeczy rozumiem, jak czytam jakieś dramaty, to potrafię zrozumieć wiele rzeczy, które dzieja się na żywo, w rzeczywistości. (Iza)

Młodzież poszukuje w lekturze również przyjemności, relaksu, zabawy, odpoczynku, jednak rozrywka nie jest obecnie główną funkcją literatury, zapewnia ją młodym ludziom przede wszystkim Internet, który jak twierdzą oni sami, zajmuje większą część ich wolnego czasu. Raczej niewiele osób traktuje czytanie jako przyjemność, czasami jest to wręcz ostateczna forma rozrywki, w przypadku kiedy np. nie ma Internetu lub nie ma innych zajęć. Okres młodzieńczy charakteryzuje się odrzuceniem starych autorytetów i poszukiwaniem nowych wzorców i modeli myślenia, odczuwania i postępowania, które pozwolą na ukształtowanie własnej osobowości. Młodzi ludzie szukają wzorców moralnych, systemów aksjonormatywnych również w literaturze.

Najważniejsze sa takie moje przemyślenia później, oceny o książe, może identyfikacja z bohaterami też, odnalezienie własnej drogi w życiu coś takiego. (Martyna)

W tym przypadku literatura spełnia funkcję wychowawczą wobec młodych ludzi, dotyczy ona moralnej sfery osobowości młodego człowieka. Wiek dorastania to okres intensywnego kształtowania obrazu siebie i świata, a także czas podejmowania decyzji i poszukiwania drogi życiowej. Jest niezmiernie istotne do jakiej literatury sięga młodzież, bowiem może mieć ona ogromny wpływ na wybór własnych wartości, własnej tożsamości oraz drogi życiowej. Wydaje się jednak, iż funkcja ta wiążąca się z poszukiwaniem wzorców i wartości moralnych nie jest szczególnie istotna dla badanych licealistów.

Podsumowując można stwierdzić, iż literatura spełnia w życiu młodych ludzi wiele funkcji, przede wszystkim pomaga w dążeniu do dalszego kształcenia, zaspokaja potrzeby przeżywania silnych wrażeń i emocji, umożliwia odprężenie, oderwanie od rzeczywistości, przezwycięża poczucie samotności, wypełniając świat bohaterami literackimi. Identyfikacja z nimi umożliwia natomiast przeżywanie różnych trudności i problemów, jakie spotykają człowieka również na co dzień, pokazując wzorce pomaga w ukształtowaniu własnej tożsamości i drogi życiowej. Wszystkie omówione powyżej funkcje składają się na edukacyjny oraz socjalizacyjny wpływ literatury. Uczenie się zachodzi bowiem poprzez kanały nieformalne i pozaformalne, przebiega przez całe życie i jest procesem globalnym. Poprzez literaturę, jej wzorce, bohaterów i świat wartości, młodzi uczą się wartości i norm obowiązujących w społeczeństwie, stając się dojrzałymi jego członkami. Niestety coraz mniej młodzieży sięga do literatury, nawet w postaci cyfrowej, co powoduje iż czerpią wzorce z innych źródeł, którymi są najczęściej różnego rodzaju media, a szczególnie Internet. Najczęściej czytaną literaturą natomiast jest obecnie literatura popularna, szczególnie literatura fantasy, w której młodzi ludzie wydają się odnajdywać realizację dla swoich potrzeb, w którą przede wszystkim uciekają przez chaosem, niepewnością i dynamizmem dzisiejszego świata. To właśnie literatura popularna spełnia większość funkcji wcześniej wspomnianych w życiu młodych ludzi, a przede wszystkim socjalizacyjną i edukacyjną. Myślę, że należy prowadzić dalsze badania dotyczące literatury popularnej i jej oddziaływa-

52 Z. Zasacka, dz. cyt., s. 24.

OGROdY NAUK I SZTUK NR 2014 (4) 
nia na młodych ludzi, szczególnie, iż ostatnio mamy dość często do czynienia z kolejnymi bestsellerami, masowo czytanymi przez młodzież, które mają ogromny wpływ na tworzenie się tożsamości młodych ludzi, ich światopogląd oraz postrzeganie rzeczywistości. Niezbędne są wobec tego badania, które pozwolą dokładnie określić wartości i znaczenie, jakie młodzież przypisuje bohaterom kultury popularnej, jakie wzorce i wartości czerpie z poszczególnych jej wytworów.

\section{Bibliografia}

[1] Bernasiewicz M., Młodzież i popkultura. Dyskursy śzwiatopogladowe, recepcja i opór, Katowice 2009.

[2] Cybal-Michalska A., Tożsamość młodzieży w perspektywie globalnego świata. Studium socjopedagogiczne, Poznań 2006.

[3] Gałuszka M., Między przyjemnością a rytuałem. Serial telewizyjny w kulturze popularnej, Łódź 1996.

[4] Jakubowski W., Edukacja w świecie kultury popularnej, Kraków 2011.

[5] Kłoskowska A., Kultura masowa. Krytyka i obrona, Warszawa 2005.

[6] Kłoskowska A., Społeczne ramy kultury. Monografia socjologiczna, Warszawa 1972.

[7] Kowalewska D., Harry i czary-mary, czyli o wartościach edukacyjnych w cyklu powieści „Harry Potter" J. K. Rowling, Kraków 2005

[8] Kowalski P., Miejsce literatury w kulturze popularnej, „Kultura Popularna” 2005, nr 2 (12)18.

[9] Melosik Z., Kultura popularna jako czynnik socjalizacji, [w:] Z. Kwieciński, B. Śliwerski (red.), Pedagogika podręcznik akademicki, T. II, Warszawa 2003.

[10] Krajewski M., Kultury kultury popularnej, Poznań 2003.

[11] Melosik Z., Młodzież a przemiany kultury wspótczesnej, [w:] Leppert R., Melosik Z., Wojtasik B. (red.), Młodzież wobec (nie) gościnnej przyszłości, Wrocław 2005.

[12] Melosik Z., Pedagogika postmodernizmu, [w:] Kwieciński Z., Śliwerski B. (red.), Pedagogika. Podręcznik akademicki, T. II, Warszawa 2003.

[13] Papuzińska J., Inicjacje literackie: problemy pierwszych kontaktów dziecka z ksiażka, Warszawa 1988

[14] Rubacha K., Edukacja jako przedmiot pedagogiki i jej subdyscyplin, [w:] Z. Kwieciński, B. Śliwerski (red.), Pedagogika podręcznik akademicki, T. II, Warszawa 2003

[15] Szacka B., Wprowadzenie do socjologii, Warszawa 2003.

[16] Szafraniec K., Wartości młodego pokolenia, [w:] Łuczewski M. (red.), Portret młodego pokolenia, „,Wolnośći solidarność” 2009, nr 13

[17] Zasacka Z., Nastoletni czytelnicy, Warszawa 2008.

\section{Netografia}

[18] Encyklopedia zarządzania, http://mfiles.pl/pl/index.php/Generacja_Y, 27.03.2012.

[19] Mały Rocznik Statystyczny Polski 2013, www.stat.gov.pl, 20.05.2012

[20] Zatorska T., Rozważania naukowe nad czytelnictwem, http://szkola.net/awans/art.php?id=2090, 26.05.2012

[21] Ziaja J., Literatura elektroniczna a czytelnictwo młodzieży akademickiej, ,,Podkarpackie Studia Biblioteczne”, nr1(2012), http://psb.univ.rzeszow.pl/ sites/default/files/pdf/literatura_elektroniczna_a_czytelnictwo_mlodziezy_akademickiej.pdf, 27.04.2013. 